
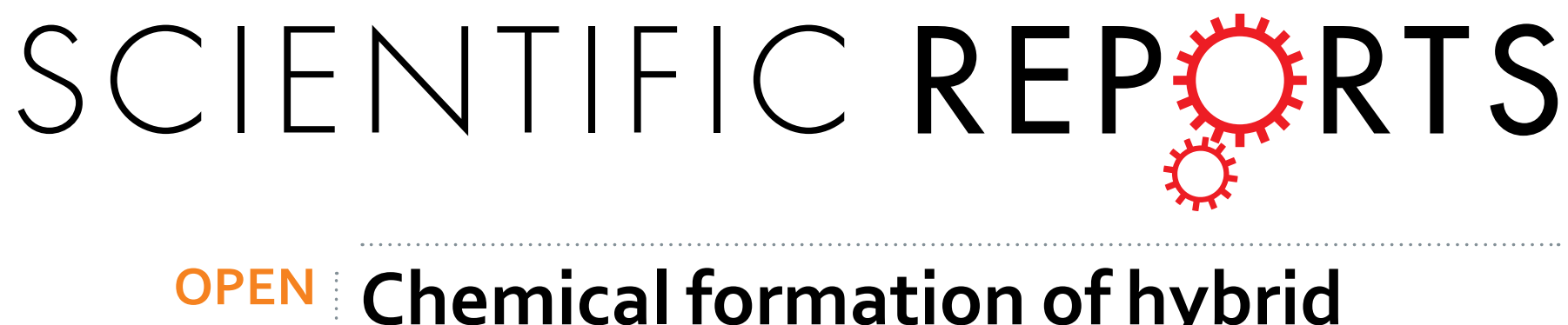

\title{
Chemical formation of hybrid di-nitrogen calls fungal codenitrification into question
}

Received: 12 July 2016

Accepted: 17 November 2016

Published: 15 December 2016

\section{Rebecca L. Phillips ${ }^{1}$, Bongkeun Song², Andrew M. S. McMillan¹, Gwen Grelet ${ }^{1}$, Bevan S. Weir ${ }^{1}$, Thilak Palmada ${ }^{1} \&$ Craig Tobias $^{3}$}

Removal of excess nitrogen $(\mathrm{N})$ can best be achieved through denitrification processes that transform $\mathrm{N}$ in water and terrestrial ecosystems to di-nitrogen $\left(\mathrm{N}_{2}\right)$ gas. The greenhouse gas nitrous oxide $\left(\mathrm{N}_{2} \mathrm{O}\right)$ is considered an intermediate or end-product in denitrification pathways. Both abiotic and biotic denitrification processes use a single $\mathrm{N}$ source to form $\mathrm{N}_{2} \mathrm{O}$. However, $\mathrm{N}_{2}$ can be formed from two distinct $\mathrm{N}$ sources (known as hybrid $\mathrm{N}_{2}$ ) through biologically mediated processes of anammox and codenitrification. We questioned if hybrid $\mathrm{N}_{2}$ produced during fungal incubation at neutral $\mathrm{pH}$ could be attributed to abiotic nitrosation and if $\mathrm{N}_{2} \mathrm{O}$ was consumed during $\mathrm{N}_{2}$ formation. Experiments with gas chromatography indicated $\mathrm{N}_{2}$ was formed in the presence of live and dead fungi and in the absence of fungi, while $\mathrm{N}_{2} \mathrm{O}$ steadily increased. We used isotope pairing techniques and confirmed abiotic production of hybrid $\mathrm{N}_{2}$ under both anoxic and $20 \% \mathrm{O}_{2}$ atmosphere conditions. Our findings question the assumptions that (1) $\mathrm{N}_{2} \mathrm{O}$ is an intermediate required for $\mathrm{N}_{2}$ formation, (2) production of $\mathrm{N}_{2}$ and $\mathrm{N}_{2} \mathrm{O}$ requires anaerobiosis, and (3) hybrid $\mathrm{N}_{2}$ is evidence of codenitrification and/or anammox. The $\mathrm{N}$ cycle framework should include abiotic production of $\mathrm{N}_{2}$.

The nitrogen $(\mathrm{N})$ removal pathway known as denitrification is typically considered a biological process, where nitrate $\left(\mathrm{NO}_{3}^{-}\right)$or nitrite $\left(\mathrm{NO}_{2}^{-}\right)$is sequentially reduced by bacteria and archaea to nitric oxide (NO), nitrous oxide $\left(\mathrm{N}_{2} \mathrm{O}\right)$ and finally inert di-nitrogen $\left(\mathrm{N}_{2}\right)^{1}$. Incomplete denitrification results in emission of $\mathrm{N}_{2} \mathrm{O}$, an important greenhouse gas now playing a primary role in stratospheric ozone depletion ${ }^{2}$. While prokaryotes are well known to denitrify ${ }^{3}$, new findings indicate denitrification by eukaryotes, such as fungi, may be widespread ${ }^{4-6}$. Unlike prokaryotes, fungi do not have the genes encoding nitrous oxide reductase, which reduces $\mathrm{N}_{2} \mathrm{O}$ to $\mathrm{N}_{2}$, so fungal denitrification terminates at $\mathrm{N}_{2} \mathrm{O}^{7,8}$. Denitrification occurs when a single $\mathrm{N}$ source is used to produce $\mathrm{N}_{2} \mathrm{O}$, such as $\mathrm{NO}_{2}^{-}$or $\mathrm{NO}_{3}{ }^{-}$. Codenitrification occurs when individual atoms of the $\mathrm{N}_{2} \mathrm{O}$ or $\mathrm{N}_{2}$ molecules are derived from two distinct $\mathrm{N}$ sources ${ }^{9,10}$, resulting in hybrid $\mathrm{N}_{2}{ }^{8}$. Formation of hybrid $\mathrm{N}_{2}$ is widely reported as evidence of anammox $^{11}$ or codenitrification ${ }^{12-14}$. Previously, isotope pairing experiments revealed chemodenitrification ${ }^{15,16}$ and denitrification by the fungi Bipolaris sorokiniana used $\mathrm{NO}_{2}{ }^{-}$as the sole source for $\mathrm{N}_{2} \mathrm{O}$ formation ${ }^{16}$. Fungal denitrification rates of $\mathrm{NO}_{2}{ }^{-}$to $\mathrm{N}_{2} \mathrm{O}$ were similar under both anaerobic and microaerophilic conditions, contrary to classical denitrification, suggesting $\mathrm{O}_{2}$ may not, in this case, be a strong regulator ${ }^{16}$.

Incubation experiments with pure cultures and soils report a number of fungi may play a significant role in soil $\mathrm{N}$ trace gas production ${ }^{5,6,17,18}$. Fungi not only denitrify to $\mathrm{N}_{2} \mathrm{O}$ but may also codenitrify to form $\mathrm{N}_{2}{ }^{8,9}$. When $\mathrm{O}_{2}$ is not available, some fungi (Fusarium oxysporum) reportedly co-metabolise organic forms of $\mathrm{N}$ to reduce $\mathrm{NO}_{2}{ }^{-}$or $\mathrm{NO}_{3}{ }^{-}$and form hybrid $\mathrm{N}_{2}^{7,9,10}$. This has been demonstrated in soils by tracing ${ }^{29} \mathrm{~N}_{2}$ and ${ }^{30} \mathrm{~N}_{2}$ following application of antibiotics to selectively inhibit bacteria or fungi ${ }^{12,14}$. Codenitrification is widely viewed as an anaerobic, enzymatically-mediated nitrosation process requiring low $(<-1)$ formal oxidation state of the nucleophilic $\mathrm{N}^{8}$. Figure 1 illustrates how anammox, like codenitrification, also forms hybrid $\mathrm{N}_{2}$, although anammox uses two forms of inorganic $\mathrm{N}, \mathrm{NO}_{2}^{-}$and ammonium $\left(\mathrm{NH}_{4}{ }^{+}\right)^{11,19}$.

The specific codenitrification pathway is unknown, but fungi reportedly reduce $\mathrm{NO}_{2}{ }^{-}$to $\mathrm{NO}$ using $\mathrm{NO}_{2}{ }^{-}$ reductase (encoded by the nirK gene) and then reduce $\mathrm{NO}$ to $\mathrm{N}_{2} \mathrm{O}$ using nitric oxide reductase (P450nor) ${ }^{7}$. The role of $\mathrm{N}_{2} \mathrm{O}$ in the codenitrification process and in $\mathrm{N}_{2}$ formation is not clear ${ }^{20}$. While utilisation of $\mathrm{N}_{2} \mathrm{O}$ to form $\mathrm{N}_{2}$

${ }^{1}$ Landcare Research, Gerald Street, Lincoln, New Zealand. ${ }^{2}$ Dept. of Biological Sciences, Virginia Institute of Marine Science, Gloucester Point, Virginia, USA. ${ }^{3}$ Dept. of Marine Sciences, University of Connecticut, Groton, Connecticut, USA. Correspondence and requests for materials should be addressed to R.L.P. (email: PhillipsR@LandcareResearch. co.nz) 


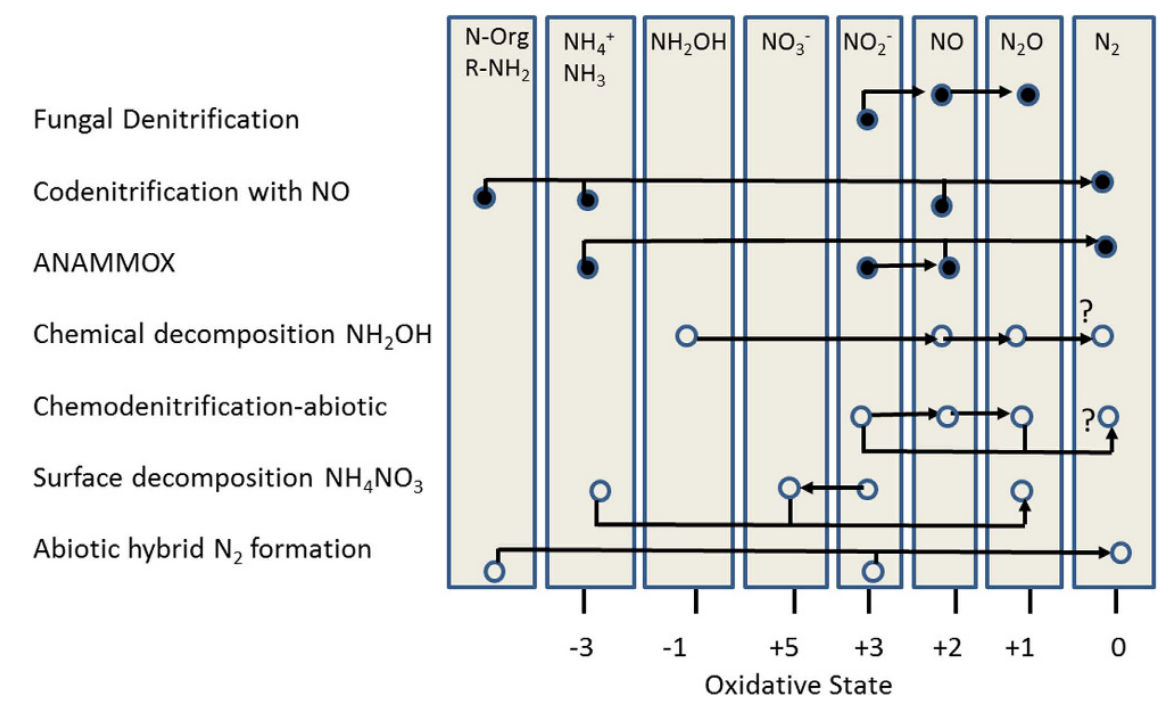

Figure 1. Schematic of codenitrification, anammox and known chemical denitrification pathways. Selected processes potentially leading to $\mathrm{N}_{2} \mathrm{O}$ and $\mathrm{N}_{2}$ formation, involved $\mathrm{N}$ compounds, their reaction pathways as well as their oxidation states are shown. Closed circles are biotic and open circles are abiotic reactions. Terms are defined as follows: $\mathrm{Norg} / \mathrm{R}-\mathrm{NH}_{2}$, monomeric organically bound $\mathrm{N}$ forms; $\mathrm{NH}_{4}{ }^{+}$, ammonium; $\mathrm{NH}_{3}$, ammonia; $\mathrm{NH}_{2} \mathrm{OH}$, hydroxylamine; $\mathrm{NO}_{2}{ }^{-}$, nitrite; $\mathrm{NO}_{3}{ }^{-}$, nitrate; $\mathrm{NO}$, nitric oxide; $\mathrm{N}_{2} \mathrm{O}$, nitrous oxide; $\mathrm{N}_{2}$, molecular dinitrogen. The last process, abiotic $\mathrm{N}_{2}$ formation, was observed in this study. Figure 1 is a truncated adaptation from Butterbach-Bahl et al. ${ }^{23}$, which is licensed under a Creative Commons Attribution License 3.0 (https:// creativecommons.org/licenses/by/3.0/).

has been suggested as a plausible codenitrification pathway ${ }^{8}$, reports of $\mathrm{N}_{2} \mathrm{O}$ consumption during fungal production of $\mathrm{N}_{2}$ (commonly observed during bacterial denitrification) ${ }^{21}$ are lacking. Potentially bypassing reduction of $\mathrm{N}_{2} \mathrm{O}$ to form $\mathrm{N}_{2}$, in addition to formation of hybrid $\mathrm{N}_{2}$, sets codenitrification and anammox apart from classical denitrification ${ }^{22}$.

Laboratory studies commonly report evidence of fungal denitrification or codenitrification when pure cultures are incubated under anaerobic or microaerophilic conditions with sterile media, consisting of carbon, $\mathrm{NO}_{2}{ }^{-}$and mineral salts $5,6,9,10,16$. However, reduced metals in the medium, such as $\mathrm{Fe}(\mathrm{II})$, could provide electrons required for abiotic reduction of $\mathrm{NO}_{2}{ }^{-}$to $\mathrm{N}_{2} \mathrm{O}$, commonly known as chemodenitrification ${ }^{15,23,24}$. Chemodenitrification occurs through nitrosylation when reduced forms of inorganic $\mathrm{N}$ react with a metal centre to form $\mathrm{N}_{2} \mathrm{O}$ in the absence of oxygen ${ }^{15,24}$. Nitrosylation may also drive abiotic formation of $\mathrm{N}_{2}$, given high concentrations of metal and $\mathrm{NO}_{2}{ }^{-25}$. Wullstein and Gilmour ${ }^{25}$ mixed 10,000 ppm N as potassium nitrite $\left(\mathrm{KNO}_{2}\right)$ with 5,000 ppm ferrous sulfate in an abiotic, anoxic reactor and recovered $15 \%$ of added $\mathrm{N}$ as $\mathrm{N}_{2}$ within $3 \mathrm{~d}$. In this case, the $\mathrm{N}_{2}$ formed would have been denitrified from a single $\mathrm{N}$ source, $\mathrm{KNO}_{2}$. Alternatively, chemical formation of hybrid $\mathrm{N}_{2}$ through nitrosation is often ignored by biologists. Abiotic nitrosation of organic matter by $\mathrm{NO}_{2}{ }^{-}$in soil was first suggested by Nelson and Bremner ${ }^{26}$ when they recovered over $20 \%$ of added $\mathrm{N}\left(5 \mathrm{mmols} \mathrm{NO}_{2}{ }^{-} \mathrm{g}^{-1}\right.$ soil) as $\mathrm{N}_{2}$ for sterile soil at neutral $\mathrm{pH}$ in helium $(\mathrm{He})$ and heliox $\left(20 \% \mathrm{O}_{2}, 80 \% \mathrm{He}\right)$ atmospheres. The isotopic composition of $\mathrm{N}_{2}$ was not reported, but they indicated soil organic matter was an important factor ${ }^{26}$. Trimmer and Prudy ${ }^{27}$ showed that deep seawater samples amended with ${ }^{15} \mathrm{NO}_{2}{ }^{-}$and ${ }^{14} \mathrm{NH}_{4}$ produced more ${ }^{29} \mathrm{~N}_{2}$ when organic $\mathrm{N}$ (allylthiourea) was added. They suggested an alternative metabolic pathway to anammox but did not address the possibility of abiotic ${ }^{29} \mathrm{~N}_{2}$ formation. Babbin et al. ${ }^{28}$ also found organic $\mathrm{N}$ enhances anammox $\mathrm{N}_{2}$ production. A common thread among chemical, anammox and fungal denitrification studies is $\mathrm{NO}_{2}{ }^{-}$. Thus, $\mathrm{NO}_{2}{ }^{-}$is a pivot-point for divergence in biological and chemical $\mathrm{N}$ trace gas production ${ }^{29}$ (Fig. 1).

Here, we pursue open questions raised by this early work regarding abiotic $\mathrm{N}$ trace gas production recently reviewed by Heil et al. ${ }^{30}$. We aimed to investigate if previously unexplored sources of $\mathrm{N}_{2} \mathrm{O}$ and $\mathrm{N}_{2}$ could be contributing to reactive $\mathrm{N}$ removal and if $\mathrm{N}_{2} \mathrm{O}$ was an intermediate in the abiotic $\mathrm{N}_{2}$-production pathway. We questioned whether $\mathrm{N}_{2}$ reportedly due to fungal codenitrification in pure culture experiments was formed abiotically in the presence and absence of $\mathrm{O}_{2}$, given diverse inorganic and organic sources of $\mathrm{N}$. New knowledge of abiotic $\mathrm{N}_{2} \mathrm{O}$ and $\mathrm{N}_{2}$ production would advance environmental $\mathrm{N}$-removal research and applications and perhaps explain some mass balance discrepancies found in isotopic pairing studies ${ }^{27,28}$.

To address these questions, we used a ubiquitous soil fungus, Bipolaris sorokiniana (Sacc.) Shoemaker [telemorph: Cochliobolus sativus (S. Ito \& Kurib.) Drechsler ex Dastur], as our model. Previously, we found that B. sorokiniana used $\mathrm{NO}_{2}{ }^{-}$as the sole source for denitrification to $\mathrm{N}_{2} \mathrm{O}$ under anaerobic and microaerophilic conditions ${ }^{16}$. We also found $\mathrm{NO}_{2}{ }^{-}$as the sole source for chemodenitrification, which accounted for 6-8\% of total $\mathrm{N}_{2} \mathrm{O}$ production ${ }^{16}$. These results prompted further inquiry regarding fungal and chemical trace gas production of $\mathrm{N}_{2}$. We aimed to more explicitly evaluate abiotic and biotic $\mathrm{N}_{2} \mathrm{O}$ and $\mathrm{N}_{2}$ production by comparing live fungi with fungal necromass incubated under strictly sterile conditions, with and without $\mathrm{O}_{2}$. Pure culture experiments have demonstrated fungal and chemical $\mathrm{N}_{2} \mathrm{O}$ production, but reports are lacking that indicate abiotic nitrosation of organic 


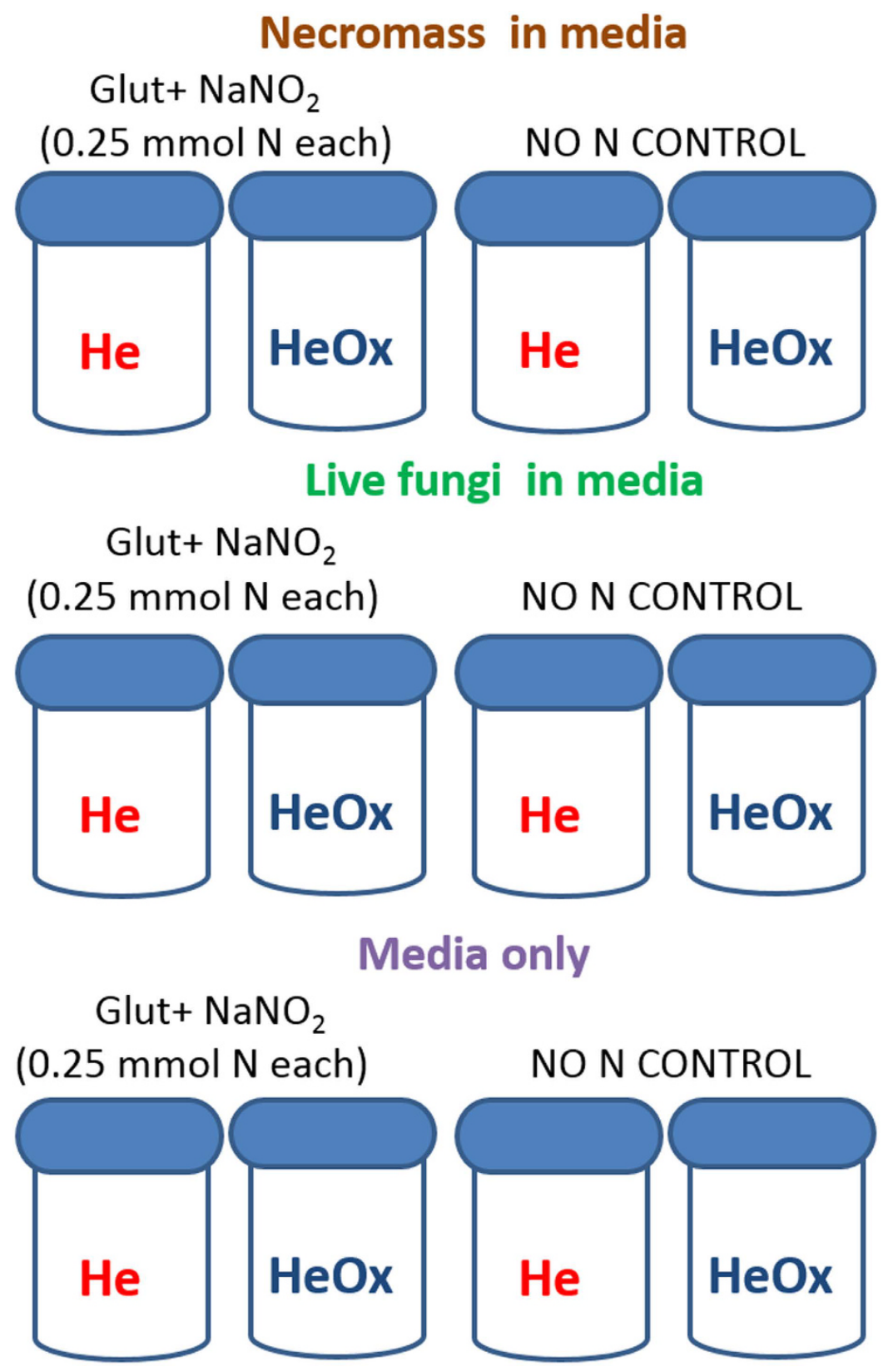

Figure 2. Experimental set-up to test how live fungi, necromass and media only incubated in an anoxic and $20 \% \mathrm{O}_{2}$ atmosphere affects production of $\mathrm{N}_{2} \mathrm{O}, \mathrm{CO}_{2}, \mathrm{O}_{2}$, and $\mathrm{N}_{2}$ following addition of both organic and inorganic forms of $\mathbf{N}$ to pure cultures under aseptic conditions. Terms are defined as: Glut, glutamine; $\mathrm{NaNO}_{2}$, sodium nitrite; He, helium; HeOx heliox.

compounds and formation of hybrid $\mathrm{N}_{2}$. We include necromass in the design because amino acids and other nucleophilic compounds from necromass could potentially, in the absence of live fungi, react with $\mathrm{NO}^{2-}$ to form $\mathrm{N}_{2}$. Further, necromass would provide more surface area for chemical decomposition of $\mathrm{NO}_{2}^{-}$to $\mathrm{N}_{2} \mathrm{O}^{24}$ (Fig. 1). This would serve as a test for abiotic formation of $\mathrm{N}_{2} \mathrm{O}$ and $\mathrm{N}_{2}$ in the presence of decomposing organic material.

We aimed to assess biotic and abiotic $\mathrm{N}_{2} \mathrm{O}$ and $\mathrm{N}_{2}$ production using established microbiological laboratory incubation methods (Fig. 2). We exposed live fungi and necromass to both inorganic and organic $\mathrm{N}$ sources $\left[0.25 \mathrm{mmol} \mathrm{N}\right.$ as sodium nitrite $\left(\mathrm{NaNO}_{2}\right)$ and $0.25 \mathrm{mmol} \mathrm{N}$ as glutamine $\left(\mathrm{C}_{5} \mathrm{H}_{10} \mathrm{~N}_{2} \mathrm{O}_{3}\right)$; concentration of $20 \mathrm{mmol} \mathrm{L}^{-1}$ each] under two $\mathrm{O}_{2}$ conditions (anaerobic and $20 \% \mathrm{O}_{2}$ ). For each treatment, there were replicate sets where $\mathrm{N}$ was not added to the media (No N control). We also included sterile media-only control vessels. Oxygen status was tightly controlled with airtight laboratory incubation vessels, where headspace was filled with either helium (anaerobic) or heliox (aerobic). Accumulation of headspace $\mathrm{O}_{2}, \mathrm{CO}_{2}, \mathrm{~N}_{2} \mathrm{O}$, and $\mathrm{N}_{2}$ were measured approximately every $6 \mathrm{~h}$ with a customised, robotic gas chromatography system ${ }^{21}$. Headspace $\mathrm{O}_{2}$ was monitored to confirmed anaerobiosis was maintained during the $30 \mathrm{~h}$ incubation. Slopes of the linear increases in $\mathrm{N}_{2} \mathrm{O}$ and $\mathrm{N}_{2}$ in the headspace of each vessel were calculated to determine production rates. We used ANOVAs to test if 


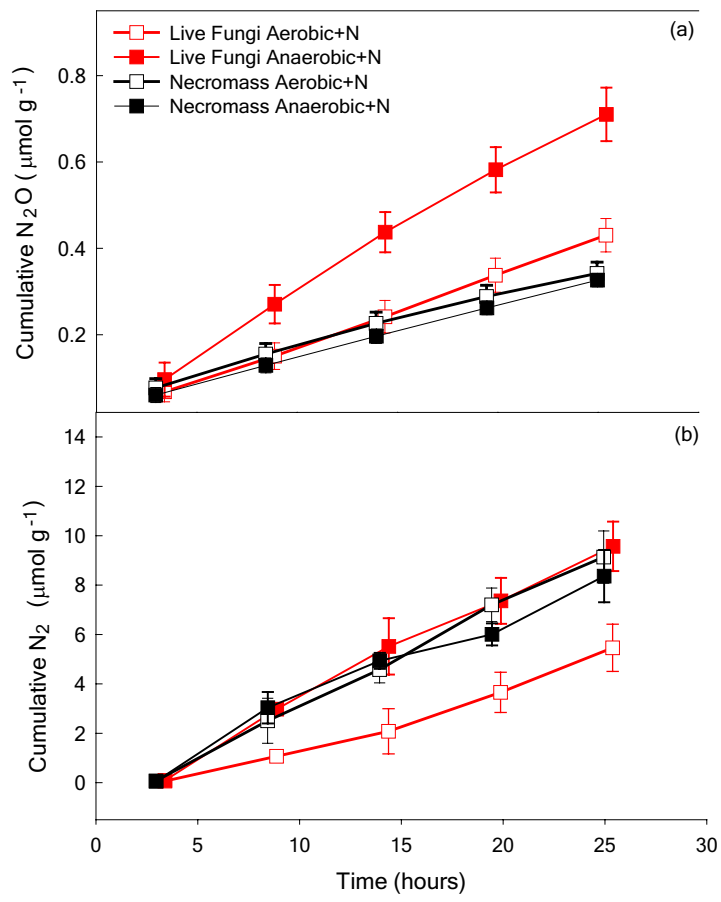

Figure 3. Kinetics of (a) $\mathrm{N}_{2} \mathrm{O}$ and (b) $\mathrm{N}_{2}$ production per g biomass over time following $\mathrm{N}$ addition at each time point as gases in the headspace accumulated. Average for each treatment are slightly staggered in time due to robotized measurement system, which is why comparisons were based on slopes over the entire incubation. Production rates of $\mathrm{N}_{2} \mathrm{O}$ and $\mathrm{N}_{2}$ were strongly affected by $\mathrm{O}_{2}$ status $\left[\mathrm{O}_{2} \times\right.$ fungal state (live or dead); $\left.\mathrm{p}<0.001\right]$ for those samples amended with N. Boxes represent average data; error bars, s.d.; $n=4$.

production of $\mathrm{N}_{2} \mathrm{O}$ and $\mathrm{N}_{2}$ by live fungi was similar to necromass, and if both groups responded similarly to $\mathrm{O}_{2}$. Production rates were calculated in units of $\mu$ mol N as $\mathrm{N}_{2} \mathrm{O}$ and $\mathrm{N}_{2} \mathrm{~g}$ fungal biomass ${ }^{-1} \mathrm{~h}^{-1}$ and in units of $\mu \mathrm{mol}$ $\mathrm{N}$ as $\mathrm{N}_{2} \mathrm{O}$ and $\mathrm{N}_{2} \mathrm{~h}^{-1}$. We performed a second incubation (illustration of this incubation design not shown) using isotope pairing techniques to determine if ${ }^{29} \mathrm{~N}_{2} \mathrm{O}$ or ${ }^{30} \mathrm{~N}_{2} \mathrm{O}$ were produced abiotically from sterile medium amended with glutamine and $\mathrm{NO}_{2}{ }^{-}$in the presence or absence of $\mathrm{O}_{2}$. We used equal amounts of unlabelled glutamine and ${ }^{15} \mathrm{~N}$-labelled $\mathrm{NO}_{2}{ }^{-}$to achieve $0.5 \mathrm{mmol} \mathrm{N}$ and $1.0 \mathrm{mmolN}$, as well as a medium that was not amended with $\mathrm{N}$.

\section{Results and Discussion}

We found both fungal states (live fungi and necromass) produced $\mathrm{N}_{2} \mathrm{O}$ and $\mathrm{N}_{2}$ but only for those samples amended with $\mathrm{N}$. Linear production of $\mathrm{N}_{2} \mathrm{O}$ and $\mathrm{N}_{2}$, following $\mathrm{N}$ amendment, occurred quickly under completely anaerobic conditions and in a $20 \% \mathrm{O}_{2}$ atmosphere (Fig. 3). Average [(standard deviation (SD)] rate of $\mathrm{N}_{2} \mathrm{O}$ produced by necromass was $0.012(<0.001) \mu \mathrm{mol} \mathrm{N}_{2} \mathrm{O}$ g biomass ${ }^{-1} \mathrm{~h}^{-1}$ under both aerobic and anaerobic conditions. Average $\mathrm{N}_{2} \mathrm{O}$ production by live fungi was $0.017(<0.001) \mu \mathrm{mol} \mathrm{N}_{2} \mathrm{O}$ g biomass ${ }^{-1} \mathrm{~h}^{-1}$ and $0.028(0.003) \mu \mathrm{mol} \mathrm{N} \mathrm{N}_{2} \mathrm{O}$ g biomass ${ }^{-1} \mathrm{~h}^{-1}$, respectively, under aerobic and anaerobic conditions (Fig. 3a). Rates of $\mathrm{N}_{2} \mathrm{O}$ production were significantly greater for live fungi incubated anaerobically $\left(\mathrm{O}_{2} \times\right.$ fungal state interaction; $\left.\mathrm{p}<0.001\right)$, indicating biological production of $\mathrm{N}_{2} \mathrm{O}$ in the absence of $\mathrm{O}_{2}$. In a $20 \% \mathrm{O}_{2}$ atmosphere, rates of $\mathrm{N}_{2} \mathrm{O}$ production were similar to necromass. Our previous study indicated B. sorokiniana produced $\mathrm{N}_{2} \mathrm{O}$ at similar rates when incubated anaerobically and in a $0.4 \% \mathrm{O}_{2}$ atmosphere ${ }^{16}$. Here, we used $20 \% \mathrm{O}_{2}$, and we found no evidence of microbial denitrification under these high- $\mathrm{O}_{2}$ conditions.

Figure 4 a provides a basis of comparison for $\mathrm{N}_{2} \mathrm{O}$ recovered in the headspace of sterile media using comparable units $\left(\mu \mathrm{mol} \mathrm{N} \mathrm{O} \mathrm{h} \mathrm{h}^{-1}\right.$ ). These data were not normalised per $\mathrm{g}$ of fungal biomass but illustrate accumulation of $\mathrm{N}_{2} \mathrm{O}$ in sterile medium relative to necromass and live fungi. Nitrous oxide production rates were greater for necromass, as compared to media only (Fig. 4a). Necromass produced an average of $0.0034 \mu \mathrm{mol} \mathrm{N}_{2} \mathrm{O} \mathrm{h}^{-1}$ at both $\mathrm{O}_{2}$ levels, as compared to $0.0011 \mu \mathrm{mol} \mathrm{N}_{2} \mathrm{O} \mathrm{h}^{-1}$ for sterile media. Greater $\mathrm{N}_{2} \mathrm{O}$ for necromass suggests the presence of decaying biomass provided greater surface area for chemodenitrification ${ }^{24}$ (Fig. 4a).

Rates of fungal $\mathrm{N}_{2} \mathrm{O}$ production observed here are lower than other reports in the literature. Maeda et al. ${ }^{6}$ found fungi carrying the nirK gene produced from 0.1 to $3.2 \mu \mathrm{mol} \mathrm{N}_{2} \mathrm{O}$ g biomass ${ }^{-1} \mathrm{~h}^{-1}$, and Rohe et al. ${ }^{31}$ reported fungal $\mathrm{N}_{2} \mathrm{O}$ production rates from 0.05 to $14 \mu$ mols $\mathrm{N}_{2} \mathrm{O} \mathrm{h}^{-1}$. In both cases, denitrification varied with fungal species and $\mathrm{N}$ amendment. Here, $B$. sorokiniana does not carry the nirK gene, which may influence $\mathrm{NO}_{2}^{-}$reduction to NO. Data on chemical formation of $\mathrm{N}_{2} \mathrm{O}$ under oxic $\left(20 \% \mathrm{O}_{2}\right)$ conditions are lacking, so these first results challenge the paradigm that chemodenitrification requires anoxia ${ }^{15}$. Contrary to chemostat studies, we included fungal necromass, which contributed to abiotic $\mathrm{N}_{2} \mathrm{O}$. Results call into question if all $\mathrm{N}_{2} \mathrm{O}$ produced in pure culture experiments $^{6,18,31}$ is enzymatically mediated if cultures include live and dead fungal or bacterial biomass. 


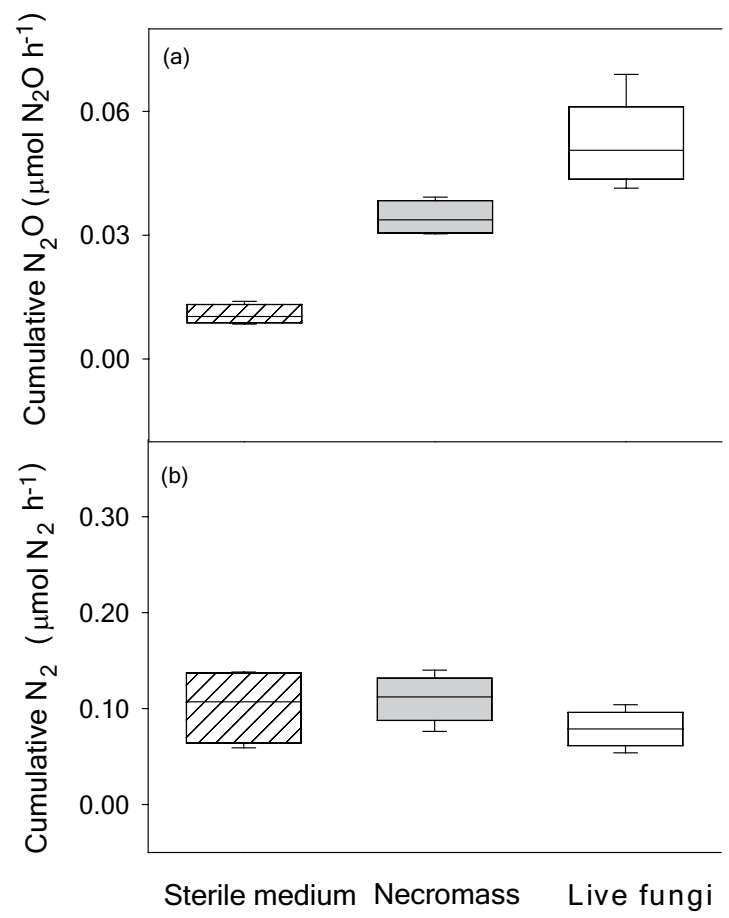

Figure 4. Abiotic and biotic contributions to rates of (a) $\mathrm{N}_{2} \mathrm{O}$ and (b) $\mathrm{N}_{2}$ accumulated per hour following $\mathrm{N}$ addition under both aerobic and anaerobic conditions for sterile medium, necromass and live fungi. Boxes represent the 90th percentile data; error bars, s.d.; $n=4$. Median values are the lines horizontally bisecting each box.

We found no evidence of biological $\mathrm{N}_{2}$ production in the presence or absence of necromass (Fig. 3b). Lowest rates of $\mathrm{N}_{2}$ production were observed for live fungi incubated in a $20 \% \mathrm{O}_{2}$ atmosphere $\left(\mathrm{O}_{2} \times\right.$ fungal state interaction; $\mathrm{p}<0.001)$. Rates of $\mathrm{N}_{2}$ produced in the headspace of live fungi were $0.243(0.039) \mu \mathrm{mol} \mathrm{N} \mathrm{g}_{2}$ biomass ${ }^{-1} \mathrm{~h}^{-1}$ and $0.424(0.049) \mu \mathrm{mol} \mathrm{N} \mathrm{g}_{2}$ biomass ${ }^{-1} \mathrm{~h}^{-1}$ under aerobic and anaerobic conditions, respectively. Rates of $\mathrm{N}_{2}$ produced in the headspace of necromass were $0.415(0.041) \mu \mathrm{mol} \mathrm{N}_{2} \mathrm{~g}_{\text {biomass }}{ }^{-1} \mathrm{~h}^{-1}$ and $0.356(0.047) \mu \mathrm{mol} \mathrm{N}_{2} \mathrm{~g}$ biomass ${ }^{-1} \mathrm{~h}^{-1}$ under aerobic and anaerobic conditions, respectively. Our results indicate there is a strong abiotic component to measured rates of $\mathrm{N}_{2}$ production and challenge the assumption that fungal $\mathrm{N}_{2}$ production ${ }^{7}$ requires anoxic or microaerophilic conditions ${ }^{8}$.

Most of the $\mathrm{N}_{2}$ accumulated in the headspace for live B. sorokiniana was commensurately found in the headspace of $B$. sorokiniana necromass (Fig. $3 \mathrm{~b}$ ), which points to chemical $\mathrm{N}_{2}$ formation. We show chemical production of $\mathrm{N}_{2}\left(\mu \mathrm{mol} \mathrm{h}^{-1}\right)$ for sterile medium relative to necromass and live fungi at both $\mathrm{O}_{2}$ levels in Fig. $4 \mathrm{~b}$. Overall average rates of $\mathrm{N}_{2}$ formation were $0.12(0.039) \mu \mathrm{mol} \mathrm{N} \mathrm{h}^{-1}$ for sterile medium, $0.11(0.024) \mu \mathrm{mol} \mathrm{N}_{2} \mathrm{~h}^{-1}$ for necromass, and $0.08(0.018) \mu \mathrm{mol} \mathrm{N}_{2} \mathrm{~h}^{-1}$ for live fungi. Others have reported much higher rates of anoxic chemical $\mathrm{N}_{2}$ formation $\left(7-32 \mu \mathrm{mol} \mathrm{N} \mathrm{h}^{-1}\right.$ ) at neutral $\mathrm{pH}$ when high concentrations of reduced metals were reacted with high concentrations of $\mathrm{NO}_{2}{ }^{-25}$ and when high $\mathrm{NO}_{2}{ }^{-}$solutions $(20 \mathrm{M})$ were added to autoclaved soil ${ }^{26}$, but these did not report if hybrid $\mathrm{N}_{2}$ was formed or not. Comparable rates of abiotic $\mathrm{N}_{2}$ production for necromass and sterile medium caused us to question if abiotic $\mathrm{N}_{2}$, like $\mathrm{N}_{2} \mathrm{O}$, could result from nitrosylation of inorganic $\mathrm{N}$ only or from nitrosation to form hybrid $\mathrm{N}_{2}$. Organic $\mathrm{N}$ has been found to increase biological production of ${ }^{29} \mathrm{~N}_{2}$ in oceanic studies ${ }^{32}$, but our results (Fig. 4b) indicated there may also be abiotic processes that contribute strongly to ${ }^{29} \mathrm{~N}_{2}$ production. Consequently, we determined if both inorganic and organic $\mathrm{N}$ were used to produce $\mathrm{N}_{2}$ abiotically in a separate, isotope pairing experiment.

The headspace above sterile media incubated under oxic and anoxic conditions with ${ }^{15} \mathrm{~N}$-labelled $\mathrm{NaNO}_{2}$ and unlabelled $\mathrm{C}_{5} \mathrm{H}_{10} \mathrm{~N}_{2} \mathrm{O}_{3}$ indicated abiotic, formation of hybrid $\mathrm{N}_{2}$. Almost all (99.9\%) of the $\mathrm{N}_{2}$ produced was ${ }^{29} \mathrm{~N}_{2}$ (Table 1). The ${ }^{29} \mathrm{~N}_{2}$ production was proportional to the mass of added $\mathrm{N}$ and approximately $3-4 \%$ of the total $\mathrm{N}$ added was transformed to ${ }^{29} \mathrm{~N}_{2}$ under both oxic and anoxic conditions and at both levels of $\mathrm{NO}_{2}{ }^{-}$addition. Results demonstrate hybrid formation of $\mathrm{N}_{2}$ is not necessarily enzymatically mediated and does not required anoxia. Formation of abiotic, hybrid $\mathrm{N}_{2}$ by two distinct inorganic $\mathrm{N}$ molecules has not been ruled out here. Previous bodies of work that use formation of ${ }^{29} \mathrm{~N}_{2}$ as evidence of anammox and/or codenitrification ${ }^{12,14,32,33}$ need to be reviewed with respect to abiotic $\mathrm{N}_{2}$ production.

Linear increases in cumulative $\mathrm{N}_{2} \mathrm{O}$ and $\mathrm{N}_{2}$ over time under aerobic and anaerobic conditions for both live fungi and necromass are shown in Fig. 3. These data suggest that $\mathrm{N}_{2} \mathrm{O}$ was not consumed during the incubation and both gases were produced independently. This finding contrasts with bacterial denitrification ${ }^{22}$, where a sharp rise in microbial production of $\mathrm{N}_{2} \mathrm{O}$ is followed by a rise in biological reduction of $\mathrm{N}_{2} \mathrm{O}$ to $\mathrm{N}_{2}$, and a drop in cumulative $\mathrm{N}_{2} \mathrm{O}$ production ${ }^{21}$. Bipolaris sorokiniana denitrifies $\mathrm{NO}_{2}^{-}$only and does not use glutamine to form $\mathrm{N}_{2} \mathrm{O}^{16}$. If the pathway to $\mathrm{N}_{2}$ were through the intermediate $\mathrm{N}_{2} \mathrm{O}$, we would expect not only $\mathrm{N}_{2} \mathrm{O}$ consumption but 


\begin{tabular}{|l|c|c|c|c|}
\hline $\begin{array}{l}\mathrm{N} \text { addition } \\
(\mathbf{m m o l ~ N})\end{array}$ & $\begin{array}{c}{ }^{29} \mathrm{~N}_{2}\left({ }^{14} \mathrm{~N},{ }^{15} \mathrm{~N}\right) \\
(\mu \mathrm{mol}) \text { aerobic }\end{array}$ & $\begin{array}{c}{ }^{30} \mathrm{~N}_{\mathbf{2}}\left({ }^{15} \mathrm{~N},{ }^{15} \mathrm{~N}\right) \\
(\mu \mathrm{mol}) \text { aerobic }\end{array}$ & $\begin{array}{c}{ }^{29} \mathrm{~N}_{2}\left({ }^{14} \mathrm{~N},{ }^{15} \mathrm{~N}\right) \\
(\mu \mathrm{mol}) \text { anaerobic }\end{array}$ & $\begin{array}{c}{ }^{30} \mathrm{~N}_{2}\left({ }^{15} \mathrm{~N},{ }^{15} \mathrm{~N}\right) \\
(\mu \mathrm{mol}) \text { anaerobic }\end{array}$ \\
\hline 0 & $-0.012(<0.001)$ & $0.000(0.000)$ & $-0.005(0.005)$ & $<0.001(<0.001)$ \\
\hline 0.5 & $16.274(2.045)$ & $0.001(<0.001)$ & $15.759(0.995)$ & $0.003(0.002)$ \\
\hline 1.0 & $40.289(2.318)$ & $0.002(<0.001)$ & $31.025(3.144)$ & $0.007(0.001)$ \\
\hline
\end{tabular}

Table 1. Average (SD) of ${ }^{29} \mathrm{~N}_{2}$ and ${ }^{30} \mathrm{~N}_{2}$ recovered in the headspace following aerobic and anaerobic incubation of sterile media at three levels of $\mathrm{N}$ addition, where added $\mathrm{N}$ comprised $50 \% \mathrm{~N}$ from unlabelled $\mathrm{C}_{5} \mathrm{H}_{10} \mathrm{~N}_{2} \mathrm{O}_{3}$ and $50 \% \mathrm{~N}$ from labelled ${ }^{15} \mathrm{~N}-\mathrm{NaNO}_{2}(\mathrm{n}=5)$. Samples were incubated for $>7 \mathrm{~d}$ prior to isotopic analyses. Values were adjusted according to helium or heliox blanks.

also accumulation of ${ }^{30} \mathrm{~N}_{2}$ in the isotopic pairing experiment. Like anammox, our abiotic $\mathrm{N}_{2}$ production results indicate $\mathrm{N}_{2} \mathrm{O}$ formation was bypassed in the pathway to $\mathrm{N}_{2}$ (Fig. 1).

We show compelling evidence that formation of ${ }^{29} \mathrm{~N}_{2}$ does not result from solely biotic nitrosation but also abiotic nitrosation. Abiotic nitrosation occurred both in the presence and absence of $\mathrm{O}_{2}$, and abiotic $\mathrm{N}_{2}$ was formed exclusively through hybridisation of inorganic and organic $\mathrm{N}$ sources and did not require the $\mathrm{N}_{2} \mathrm{O}$ intermediary. Experimental protocols, including $\mathrm{N}$ concentrations, were in accordance with fungal denitrification ${ }^{6,16}$ and codenitrification ${ }^{10}$ studies but in the absence of soils and sediments. In soil, $\mathrm{NO}^{2-}$ accumulates when excess free $\mathrm{NH}_{3}$ inhibits bacterial $\mathrm{NO}_{2}{ }^{-}$oxidation, which is often a consequence of urea hydrolysis ${ }^{30}$. Venterea et al. ${ }^{34}$ recovered 3-60\% of added urea $\mathrm{N}_{\text {as }} \mathrm{NO}_{2}{ }^{-}$, suggesting high soil $\mathrm{NO}^{2-}$ is likely following urea addition (depending upon conditions and application rate). Based on these data ${ }^{34}$, a 1-kg bovine urine addition to soil ( $\mathrm{N}$ concentration of $\left.0.4 \mathrm{mmol} \mathrm{kg}^{-1}\right)^{35}$ could result in up to $0.24 \mathrm{mmol} \mathrm{NO}_{2}^{-}$. Here, we added $0.25 \mathrm{mmol} \mathrm{NO}_{2}^{-}$to $10 \mathrm{ml}$ of fungal culture, which is on the high end of this scale. While we would expect abiotic formation of hybrid $\mathrm{N}_{2}$ via nitrosation of organic $\mathrm{N}$ to be more likely in grazed or fertilised agroecosystems, further $\mathrm{N}_{2}$ investigations with soil and at lower $\mathrm{NO}_{2}{ }^{-}$levels are needed to bridge the gap between pure culture and environmental applications.

Other areas where $\mathrm{NO}_{2}{ }^{-}$could accumulate include laboratory incubations where antibiotic inhibitors are added to soil and used to partition $\mathrm{N}_{2}$ and $\mathrm{N}_{2} \mathrm{O}$ production into fungal and bacterial contributions ${ }^{12,14}$. These data may be subject to artefacts if antibiotics repress $\mathrm{NO}_{2}{ }^{-}$oxidation, leading to $\mathrm{NO}_{2}{ }^{-}$accumulation and potential abiotic formation of $\mathrm{N}_{2}$ and/or $\mathrm{N}_{2} \mathrm{O}$. Our report also calls into question if codenitrification alone accounts for $\mathrm{N}_{2}$ and $\mathrm{N}_{2} \mathrm{O}$ emissions following high doses of $\mathrm{N}$ as urea (approximately 9 mmol g ${ }^{-1}$ soil) ${ }^{13}$ and/or $\mathrm{NO}_{2}{ }^{-}$ $\left(166 \mathrm{mmol} \mathrm{L}^{-1}\right)^{10}$. If abiotic, hybrid $\mathrm{N}_{2}$ is formed under these conditions, our understanding of soil fungal codenitrification and $\mathrm{N}$ trace gas emissions would need to be re-examined. We offer new insight into chemodenitrification of $\mathrm{NO}_{2}{ }^{-}$to $\mathrm{N}_{2}$ and present an alternative ' $\mathrm{N}_{2} \mathrm{O}$ bypass pathway'. Finally, we conclude the potential for aerobic, abiotic removal of excess reactive $\mathrm{N}$ in terrestrial and aquatic ecosystems presents environmental mitigation research opportunities, particularly where transitory or chronic $\mathrm{NO}_{2}{ }^{-}$accumulation occurs.

\section{Methods}

Fungal incubations were conducted as described in Phillips et al. (2016) with the same culture ICMP 6809 isolated as a pathogen of Hordeum distichon in New Zealand. (https://scd.landcareresearch.co.nz/Specimen/ICMP_6809) GenBank: KU194490. We used laboratory incubations and controlled $\mathrm{O}_{2}$ status to evaluate if rates of $\mathrm{N}_{2} \mathrm{O}, \mathrm{N}_{2}$ and $\mathrm{CO}_{2}$ production rates vary with aerobic conditions, as commonly reported for bacteria ${ }^{20}$. Experimental design was similar to previous work ${ }^{16}$, with 4 replicates for each treatment $\left(\mathrm{N}\right.$ with and without $\mathrm{O}_{2}$; no N with or without $\mathrm{O}_{2}$ ). Cultures were grown in medium similar to other fungal denitrification studies ${ }^{9,10,31}$, consisting of $1 \%$ glucose, $0.2 \%$ peptone and inorganic salts ${ }^{5,36}$. The only $\mathrm{N}$ source in this medium used for fungal growth was peptone. One day prior to the experiment, the growth medium was washed off cultures and replaced with the same medium that was identical except it was free of peptone and so contained no N. Using the peptone-free medium herein, two amendment solutions were prepared for fungal inoculation: (a) media without $\mathrm{N}$ and (b) $0.25 \mathrm{mmolN}$ as $\mathrm{NaNO}_{2}$ and $0.25 \mathrm{mmolN}$ as $\mathrm{C}_{5} \mathrm{H}_{10} \mathrm{~N}_{2} \mathrm{O}_{3}$. Nitrogen concentration was $0.04 \mathrm{mmol} \mathrm{N} \mathrm{L}^{-1}$. Necromass was obtained by heating live $B$. sorokiniana at $60^{\circ} \mathrm{C}$ for $48 \mathrm{~h}$. Cell death was confirmed by (a) microscopy and (b) lack of $\mathrm{CO}_{2}$ respiration over a $24 \mathrm{~h}$ period under aerobic and anaerobic conditions. Approximately $10 \mathrm{ml}$ live fungi or fungal necromass were blindly pipetted by a second independent scientist into $0.125 \mathrm{~L}$ serum bottles that were then amended with either media that included $0.25 \mathrm{mmol} \mathrm{N}$ as $\mathrm{NaNO}_{2}$ and $0.25 \mathrm{mmolN}$ as $\mathrm{C}_{5} \mathrm{H}_{10} \mathrm{~N}_{2} \mathrm{O}_{3}$ or media without $\mathrm{N}$ and mixed gently. Additional bottles containing sterile media solutions (with and without $\mathrm{N}$ ) only and without fungi were also prepared. Oxygen status was controlled with airtight laboratory incubation vessels for all necromass, live fungi and media only samples. Headspace of each sample was evacuated and filled with either $\mathrm{He}$ (anaerobic) or heliox [aerobic $\left(80 \% \mathrm{He}, 20 \% \mathrm{O}_{2}\right)$ ] within $2 \mathrm{hr}$ following inoculation ${ }^{18,20}$. Headspace gases were quantified approximately every $6 \mathrm{~h}$ at $19^{\circ} \mathrm{C}$ using a robotic gas chromatograph (GC) fitted with electron capture and thermal conductivity detectors according to McMillan et al. ${ }^{21}$. Helium or heliox blank standards were included in each GC run. Cumulative production rates were calculated as slopes of the masses ( $\mu$ mol) of $\mathrm{N}_{2} \mathrm{O}$ or $\mathrm{N}_{2}$ measured over time (h) per g of fungal biomass. Vessels incubated in He remained anoxic with the exception of necromass, where we observed $0.05 \% \mathrm{O}_{2}$. Vessels incubated in heliox remained above $19 \% \mathrm{O}_{2}$ with the exception of live fungi incubated without $\mathrm{N}$, where $5 \%$ of the headspace $\mathrm{O}_{2}$ was consumed. As reported previously, addition of $\mathrm{NO}_{2}^{-}$inhibited $\mathrm{O}_{2}$ consumption and $\mathrm{CO}_{2}$ respiration by live fungi ${ }^{16}$. Fungal biomass was determined as the difference in mass with and without media after air-drying each vessel post-incubation ${ }^{16}$. For comparisons with sterile media, rates were also calculated as slopes of the masses $(\mu \mathrm{mol})$ of $\mathrm{N}_{2} \mathrm{O}$ and $\mathrm{N}_{2}$ measured over time. Sterility was maintained and conditions remained constant, including $\mathrm{pH}$ (6.2-6.9). Sterility was tested at the end of gas sampling by pipetting $200 \mu \mathrm{L}$ medium used in the experiment onto blood agar plates and incubating 
under aerobic, anaerobic (AnaeroGen ${ }^{\mathrm{TM}}$, Thermo Scientific), and enriched $\mathrm{CO}_{2}\left(3.5-9 \%\right.$; $\mathrm{CO}_{2} \mathrm{Gen}^{\mathrm{TM}}$, Thermo Scientific) conditions. Further, medium was also pipetted onto yeast nutrient agar, brain heart infusion agar, and potato dextrose agar plates under aerobic conditions. No evidence of fungal or bacterial growth was observed following 3, 7, and $10 \mathrm{~d}$ incubations at $26^{\circ} \mathrm{C}$. Data were analysed to test for effects of $\mathrm{O}_{2}$ and live fungi on either $\mathrm{N}_{2} \mathrm{O}$ or $\mathrm{N}_{2}$ production rates with a generalised linear model. We analysed only those samples amended with $\mathrm{N}$ because samples without $\mathrm{N}$ did not produce $\mathrm{N}_{2} \mathrm{O}$ or $\mathrm{N}_{2}$. Log transformations were employed when data did not meet the assumptions of normality. Treatments variances met assumptions of homoscedasticity. All interactions were tested and remained in the model if significant.

Di-nitrogen isotopes were evaluated in a separate experiment to assess sources of $\mathrm{N}$ used in abiotic production of $\mathrm{N}_{2}$ by adding $\mathrm{Na}^{15} \mathrm{NO}_{2}$ and $\mathrm{C}_{5} \mathrm{H}_{10} \mathrm{~N}_{2} \mathrm{O}_{3}$ to sterile medium at neutral $\mathrm{pH}$, as described above. We aimed to determine if $\mathrm{N}_{2}$ would be produced through combination of ${ }^{15} \mathrm{NO}_{2}$ only (thus forming ${ }^{30} \mathrm{~N}_{2}$ ) or through combination of both $\mathrm{C}_{5} \mathrm{H}_{10} \mathrm{~N}_{2} \mathrm{O}_{3}$ and ${ }^{15} \mathrm{NO}_{2}$ (thus forming the hybrid ${ }^{29} \mathrm{~N}_{2}$ ) for $\mathrm{N}$-enriched medium relative to no- $\mathrm{N}$ medium only. In this experiment, we used five replicates at three levels of $\mathrm{N}$ : (a) no-N, (b) $0.25 \mathrm{mmol} \mathrm{NaNO}_{2}$ and $0.25 \mathrm{mmol} \mathrm{C}_{5} \mathrm{H}_{10} \mathrm{~N}_{2} \mathrm{O}_{3}$, and (c) $0.5 \mathrm{mmol} \mathrm{NaNO}_{2}$ and $0.5 \mathrm{mmol} \mathrm{C}_{5} \mathrm{H}_{10} \mathrm{~N}_{2} \mathrm{O}_{3}$. We used the same concentration of $\mathrm{N}$ in each $\mathrm{N}$ treatment but doubled the mass of $\mathrm{N}$ added. Vials were prepared under aerobic and anaerobic conditions as described previously and accompanied by He blanks. The aerobic experiment was conducted separately from the anaerobic experiment, which obviated testing for effects of $\mathrm{O}_{2}$ on masses of ${ }^{29} \mathrm{~N}_{2}$ and ${ }^{30} \mathrm{~N}_{2}$. Headspace ${ }^{29} \mathrm{~N}_{2}$ and ${ }^{30} \mathrm{~N}_{2}$ were measured on a continuous-flow isotope ratio mass spectrometer (Thermo Finnigan Delta $\mathrm{V}$, Thermo Scientific) in line with an automated gas bench interface (Thermo Gas Bench II). Precision of the isotopic analysis was $<0.001$ atom $\%$.

\section{References}

1. Zumft, W. G. Cell biology and molecular basis of denitrification. Microbiol. Molec. Biol. Rev. 61, 533-616 (1997).

2. Ravishankara, A. R., Daniel, J. S. \& Portmann, R. W. Nitrous oxide $\left(\mathrm{N}_{2} \mathrm{O}\right)$ : The dominant ozone-depleting substance emitted in the 21 st century. Science 326, 123-125; doi: 10.1126/science.1176985 (2009).

3. Philippot, L., Hallin, S. \& Schloter, M. Ecology of denitrifying prokaryotes in agricultural soil. Adv. Agron. 96, 249; doi: 10.1016/ S0065-2113(07)96003-4 (2007).

4. Yang, H., Gandhi, H., Ostrom, N. E. \& Hegg, E. L. Isotopic fractionation by a fungal P450 nitric oxide reductase during the production of $\mathrm{N}_{2} \mathrm{O}$. Environ. Sci.Tech. 48, 10707-10715; doi: 10.1021/es501912d (2014).

5. Rohe, L. et al. Fungal oxygen exchange between denitrification intermediates and water. Rapid Comm. Mass Spectrom. 28, 377-384; doi: $10.1002 / \mathrm{rcm} .6790$ (2014).

6. Maeda, K. et al. $\mathrm{N}_{2} \mathrm{O}$ production, a widespread trait in fungi. Sci. Rep. 5, 9697; doi: 10.1038/srep09697 (2015).

7. Shoun, H., Fushinobu, S., Jiang, L., Kim, S. \& Wakagi, T. Fungal denitrification and nitric oxide reductase cytochrome P450nor. Philosoph. Trans. Royal Soc. B: Biol. Sci. 367, 1186-1194; doi: 10.1098/rstb.2011.0335 (2012).

8. Spott, O., Russow, R. \& Stange, C. F. Formation of hybrid $\mathrm{N}_{2} \mathrm{O}$ and hybrid $\mathrm{N}_{2}$ due to codenitrification: First review of a barely considered process of microbially mediated N-nitrosation. Soil Biology and Biochemistry 43, 1995-2011; doi: 10.1016/j. soilbio.2011.06.014 (2011).

9. Tanimoto, T., Hatano, K.-i., Kim, D.-h., Uchiyama, H. \& Shoun, H. Co-denitrification by the denitrifying system of the fungus Fusarium oxysporum. FEMS Microbiol. Lett. 93, 177-180; doi: 10.1111/j.1574-6968.1992.tb05086.x (1992).

10. Shoun, H., Kim, D.-H., Uchiyama, H. \& Sugiyama, J. Denitrification by fungi. FEMS Microbiology Letters 94, 277-281; doi: 10.1111/ j.1574-6968.1992.tb05331.x (1992).

11. Kuypers, M. M. M. et al. Massive nitrogen loss from the Benguela upwelling system through anaerobic ammonium oxidation. Proc. Nat. Acad. Sci., USA 102, 6478-6483; doi: 10.1073/pnas.0502088102 (2005).

12. Long, A., Heitman, J., Tobias, C., Phillips, R. \& Song, B. Co-occurring anammox, denitrification, and codenitrification in agricultural soils. Appl. Environ. Microbiol. 79, 168-176; doi: 10.1128/aem.02520-12 (2013).

13. Selbie, D. R. et al. Confirmation of co-denitrification in grazed grassland. Sci. Rep. 5, 17361; doi: 10.1038/srep17361 (2015).

14. Laughlin, R. J. \& Stevens, R. J. Evidence for fungal dominance of denitrification and codenitrification in a grassland soil. Soil Sci. Soc. Amer. J. 66, 1540-1548 (2002).

15. Jones, L. C., Peters, B., Lezama Pacheco, J. S., Casciotti, K. L. \& Fendorf, S. Stable isotopes and iron oxide mineral products as markers of chemodenitrification. Environ. Sci. Tech. 49, 3444-3452; doi: 10.1021/es504862x (2015).

16. Phillips, R. L. et al. Fungal denitrification: Bipolaris sorokiniana exclusively denitrifies inorganic nitrogen in the presence and absence of oxygen. FEMS MIcrobiol. Lett. 363; doi: 10.1093/femsle/fnw007 (2016).

17. Sutka, R. L., Adams, G. C., Ostrom, N. E. \& Ostrom, P. H. Isotopologue fractionation during $\mathrm{N}_{2} \mathrm{O}$ production by fungal denitrification. Rapid Comm. Mass Spectrom. 22, 3989-3996; doi: 10.1002/rcm.3820 (2008).

18. Zhou, Z., Takaya, N., Sakairi, M. A. C. \& Shoun, H. Oxygen requirement for denitrification by the fungus Fusarium oxysporum. Arch. Microbiol. 175, 19-25; doi: 10.1007/s002030000231 (2001).

19. Schmid, M. C. et al. Anaerobic ammonium-oxidizing bacteria in marine environments: Widespread occurrence but low diversity. Environ. Microbiol. 9, 1476-1484 (2007).

20. Butterbach-Bahl, K., Baggs, E. M., Dannenmann, M., Kiese, R. \& Zechmeister-Boltenstern, S. Nitrous oxide emissions from soils: how well do we understand the processes and their controls? Phil. Trans.Royal Soc. B: Biol. Sci. 368, 20120122; doi: 10.1098/ rstb.2013.0122 (2013).

21. McMillan, A. M. S. et al. Can $\mathrm{pH}$ amendments in grazed pastures help reduce $\mathrm{N}_{2} \mathrm{O}$ emissions from denitrification? - The effects of liming and urine addition on the completion of denitrification in fluvial and volcanic soils. Soil Biol. Biochem. 93, 90-104; doi: http:// dx.doi.org/10.1016/j.soilbio.2015.10.013 (2016).

22. Firestone, M. K. \& Tiedje, J. M. Temporal change in nitrous oxide and dinitrogen from denitrification following onset of anaerobiosis. Appl. Environ. Microbiol. 38, 673-679; doi: http://aem.asm.org/content/38/4/673 (1979).

23. Moraghan, J. \& Buresh, R. Chemical reduction of nitrite and nitrous oxide by ferrous iron. Soil Sci. Soc. Amer. J. 41, 47-50 (1977).

24. Kampschreur, M. J. et al. Emission of nitrous oxide and nitric oxide from a full-scale single-stage nitritation-anammox reactor. Water Sci. Tech. 60, 3211-3217 (2009).

25. Wullstein, L. H. \& Gilmour, C. M. Non-enzymatic formation of nitrogen gas. Nature 210, 1150-1151; doi: 10.1038/2101150a0 (1966).

26. Nelson, D. W. \& Bremner, J. M. Gaseous products of nitrite decomposition in soils. Soil Biol. Biochem. 2, 203-IN208; doi: 10.1016/0038-0717(70)90008-8 (1970).

27. Trimmer, M. \& Purdy, K. J. Evidence for the direct oxidation of organic nitrogen to $\mathrm{N}_{2}$ gas in the Arabian Sea. ISME J. 6, 1798-1800; doi: 10.1038/ismej2012.18 (2012).

28. Babbin, A. R., Keil, R. G., Devol, A. H. \& Ward, B. B. Organic matter stoichiometry, flux and oxygen control nitrogen loss in the ocean. Science 344, 406-408; doi: 10.1126/science.1248364 (2014). 
29. Venterea, R. T. Nitrite-driven nitrous oxide production under aerobic soil conditions: kinetics and biochemical controls. Global Change Biology 13, 1-12; doi: 10.1111/j.1365-2486.2007.01389.x (2007).

30. Heil, J., Vereecken, H. \& Bruggemann, N. A review of chemical reactions of nitrification intermediates and their role in nitrogen cycling and nitrogen trace gas formation in soil. Europ. J. Soil Sci. 67, 23-39; doi: 10.1111/ejss.12306 (2016).

31. Rohe, L. et al. Dual isotope and isotopomer signatures of nitrous oxide from fungal denitrification - a pure culture study. Rapid Comm. Mass Spectrom. 28, 1893-1903; doi: 10.1002/rcm.6975 (2014).

32. Zhu, G. et al. Occurrence, activity and contribution of anammox in some freshwater extreme environments. Environ. Microbiol. Rep. (2015).

33. Ward, B. B. et al. Denitrification as the dominant nitrogen loss process in the Arabian Sea. Nature 461, 78-81; doi: 10.1038/ nature08276 (2009).

34. Venterea, R. T. et al. Ammonium sorption and ammonia inhibition of nitrite-oxidizing bacteria explain contrasting soil $\mathrm{N}_{2} \mathrm{O}$ production. Scientific Reports 5, 12153, doi: 10.1038/srep12153; http://www.nature.com/articles/srep12153\#supplementaryinformation (2015).

35. Hoogendoorn, C. J., Betteridge, K., Costall, D. A. \& Ledgard, S. F. Nitrogen concentration in the urine of cattle, sheep and deer grazing a common ryegrass/cocksfoot/white clover pasture. New Zealand J. Agri. Res. 53, 235-243; doi: 10.1080/00288233.2010.499899 (2010).

36. Marx, D. H. \& Bryan, W. C. Growth and ectomycorrhizal development of loblolly pine seedlings in fumigated soil infested with the fungal symbiont Pisolithus tinctorius. For. Sci. 21, 245-254; doi: 10.1080/00288233.2010.499899 (1975).

\section{Acknowledgements}

The authors thank the team at Landcare Research in New Zealand for supporting this idea. This work was partially funded by a USDA-NIFR grant [2014-67019-21614]; New Zealand's Ministry of Business Innovation and Employment, Royal Society of New Zealand International Travel Programme; and New Zealand Ecosystems and Global Change Fund. The authors are grateful to Veronica Rollinson, Sujatha Senanayake, Duckchul Park, and Megan Peterson for technical assistance and Bill Schlesinger, Iris Anderson, Neha Jha, Mikki Eken, and Leah Kearns for their comments, support and editorial reviews.

\section{Author Contributions}

R.L.P., B.S. and G.G. designed the experiments, T.P. performed lab experiments, A.M.S.M. analysed chromatographic data, C.T. performed isotope pairing experiments, B.S.W. and G.G. cultured, and verified fungal isolates, and R.L.P. and B.S. wrote the manuscript.

\section{Additional Information}

Competing financial interests: The authors declare no competing financial interests.

How to cite this article: Phillips, R. L. et al. Chemical formation of hybrid di-nitrogen calls fungal codenitrification into question. Sci. Rep. 6, 39077; doi: 10.1038/srep39077 (2016).

Publisher's note: Springer Nature remains neutral with regard to jurisdictional claims in published maps and institutional affiliations.

(c) (i) This work is licensed under a Creative Commons Attribution 4.0 International License. The images or other third party material in this article are included in the article's Creative Commons license, unless indicated otherwise in the credit line; if the material is not included under the Creative Commons license, users will need to obtain permission from the license holder to reproduce the material. To view a copy of this license, visit http://creativecommons.org/licenses/by/4.0/

(c) The Author(s) 2016 


\section{SCIENTIFIC REP:RTS}

OPEN Corrigendum: Chemical formation

\section{of hybrid di-nitrogen calls fungal codenitrification into question}

Rebecca L. Phillips, Bongkeun Song, Andrew M. S. McMillan, Gwen Grelet, Bevan S. Weir, Thilak Palmada \& Craig Tobias

Scientific Reports 6:39077; doi: 10.1038/srep39077; published online 15 December 2016; updated 22 December 2017

This Article contains typographical errors in the Introduction section.

"We performed a second incubation (illustration of this incubation design not shown) using isotope pairing techniques to determine if ${ }^{29} \mathrm{~N}_{2} \mathrm{O}$ or ${ }^{30} \mathrm{~N}_{2} \mathrm{O}$ were produced abiotically from sterile medium amended with glutamine and $\mathrm{NO}_{2}{ }^{-}$in the presence or absence of $\mathrm{O}_{2}{ }^{\prime \prime}$.

should read:

"We performed a second incubation (illustration of this incubation design not shown) using isotope pairing techniques to determine if ${ }^{29} \mathrm{~N}_{2}$ or ${ }^{30} \mathrm{~N}_{2}$ were produced abiotically from sterile medium amended with glutamine and $\mathrm{NO}_{2}{ }^{-}$in the presence or absence of $\mathrm{O}_{2}$ ".

(i) This work is licensed under a Creative Commons Attribution 4.0 International License. The images or other third party material in this article are included in the article's Creative Commons license, unless indicated otherwise in the credit line; if the material is not included under the Creative Commons license, users will need to obtain permission from the license holder to reproduce the material. To view a copy of this license, visit http://creativecommons.org/licenses/by/4.0/

(C) The Author(s) 2017 